\title{
Assignment of PCR markers to river buffalo chromosomes
}

\author{
Hanaa A. Oraby ${ }^{a}$, Soheir M. El Nahas ${ }^{a *}, \mathrm{H}$. Anna de Hondt ${ }^{\mathrm{a}}$, \\ Akmal El Ghor ${ }^{b}$, Mohamed F. Abdel Samad ${ }^{a}$ \\ ${ }^{\text {a }}$ Department of Cell Biology, National Research Centre, Dokki, Cairo, Egypt \\ ${ }^{\mathrm{b}}$ Department of Zoology, Faculty of Science, Cairo University, Cairo, Egypt
}

(Received 4 June 1997; accepted 25 September 1997)

\begin{abstract}
In the process of developing a buffalo physical map using somatic cell hybrids and the cattle gene map as a template, ten PCR primers designed for four coding genes: F10, FSHB, HBB, and CYM and six DNA segments: TGLA9, TGLA227, UWCA5, CSSM6, CSSM47 and RF131 were tested on a panel of 47 buffalo-hamster somatic cell hybrids. F10-TGLA9, FSHB-HBB and UWCA5-TGLA227, respectively, were found to segregate together forming three syntenic groups. These three syntenic groups have also been reported in cattle, where they have been assigned to chromosomes BTA 12, BTA 15 and BTA 18, respectively. Comparative mapping predicts the assignment of these syntenic groups to river buffalo chromosomes BBU 13, BBU 16 and BBU 18, respectively. (c) Inra/Elsevier, Paris
\end{abstract}

buffalo / chromosome / synteny / PCR markers / gene mapping

Résumé - Assignation de marqueurs PCR aux chromosomes du buffle de rivière. Dans le but de développer la carte génétique physique du buffle en utilisant l'hybridation cellulaire somatique et la carte génétique bovine comme référence, dix amorces PCR correspondant à quatre gènes codants : F10, FSHB, HBB et CYM et six segments d'ADN : TGLA9, TGLA227, UWCA5, CSSM6, CSSM47 et RF131 on été testés sur une série de 47 hybrides cellulaires somatiques entre buffle et hamster. F10-TGLA9, FSHB-HBB et UWCA5-TGLA227, respectivement, ont été trouvés ségréger ensemble pour former trois groupes synténiques. Ceux-ci ont été aussi observés chez les bovins où ils ont été assignés aux chromosomes BTA 12, BTA 15 et BTA 18, respectivement. Les cartes comparées permettent de prédire une assignation respective des trois groupes synténiques aux chromosomes BBU 13, BBU 16 et BBU 18 du buffle de rivière. (c) Inra/Elsevier, Paris buffle / chromosome / synténie / marqueurs PCR / carte génétique

\footnotetext{
* Correspondence and reprints
} 


\section{INTRODUCTION}

The establishment of a physical gene map of the buffalo genome is an important step towards identifying and cloning loci controlling physiological and quantitative traits. There is a high level of syntenic and chromosomal conservation among members of the family Bovidae [38]. Therefore, inferences can be made concerning the expected location of markers in one species from information available in another species. Several genes previously assigned to cattle syntenic groups and/or chromosomes have been assigned to buffalo chromosomes $[6,7,10,11,18,19,23$, $24,28]$.

The aim of the present work was to investigate the syntenic relationship of ten markers in buffalo, and to map them to buffalo chromosomes on the basis of the comparative banding homoeology between buffalo and cattle.

\section{MATERIALS AND METHODS}

Ten PCR primers designed to amplify bovine specific sequences were used. The PCR primers represented four coding genes: coagulation factor $\mathrm{X}$ (F10), follicle stimulating hormone (FSHB), beta hemoglobin (HBB), and prochymosin pseudogene (CYM), in addition to six DNA markers, namely: TGLA9, TGLA227, UWCA5, CSSM6, CSSM47 and RF131.

Forty-seven somatic hybrid cell lines were developed as described previously [6] from fusion between buffalo lymphocytes and the Chinese hamster cell line wg3h [9]. Genomic DNA was extracted from buffalo lymphocytes, the parental hamster cell line and the 47 hybrid somatic cell clones, according to established protocols [4].

The PCR was performed using Taq polymerase obtained from Promega and the buffer recommended by the manufacturer. For each locus the PCR was carried out in a $25 \mu \mathrm{L}$ reaction mixture consisting of $0.2 \mathrm{mM}$ dNTPs, $10 \mathrm{mM}$ Tris, $50 \mathrm{mM} \mathrm{KCl}$, $1.5 \mathrm{mM} \mathrm{MgCl} 2,0.01 \%$ gelatin (w/v), $0.125 \%$ units Taq polymerase and $1 \mu \mathrm{M}$ upper and lower primers. It was distributed into PCR tubes with $100 \mathrm{ng}$ DNA of buffalo, hamster or hybrid cells. The reaction mixture was overlaid with sterile mineral oil and was run in a Coy Temp Cycler II under the optimum conditions for each primer (table $I$ ). PCR reaction products were subjected to $3 \%$ agarose gel electrophoresis, stained with ethidium bromide, and scored for the presence or absence of river buffalo-specific PCR products.

\subsection{Statistical analysis}

Pairwise analysis, based on percentage concordances and correlation coefficients [5] of the segregation profiles of buffalo-specific PCR products, was carried out on the 47 buffalo-hamster somatic cell hybrids. 


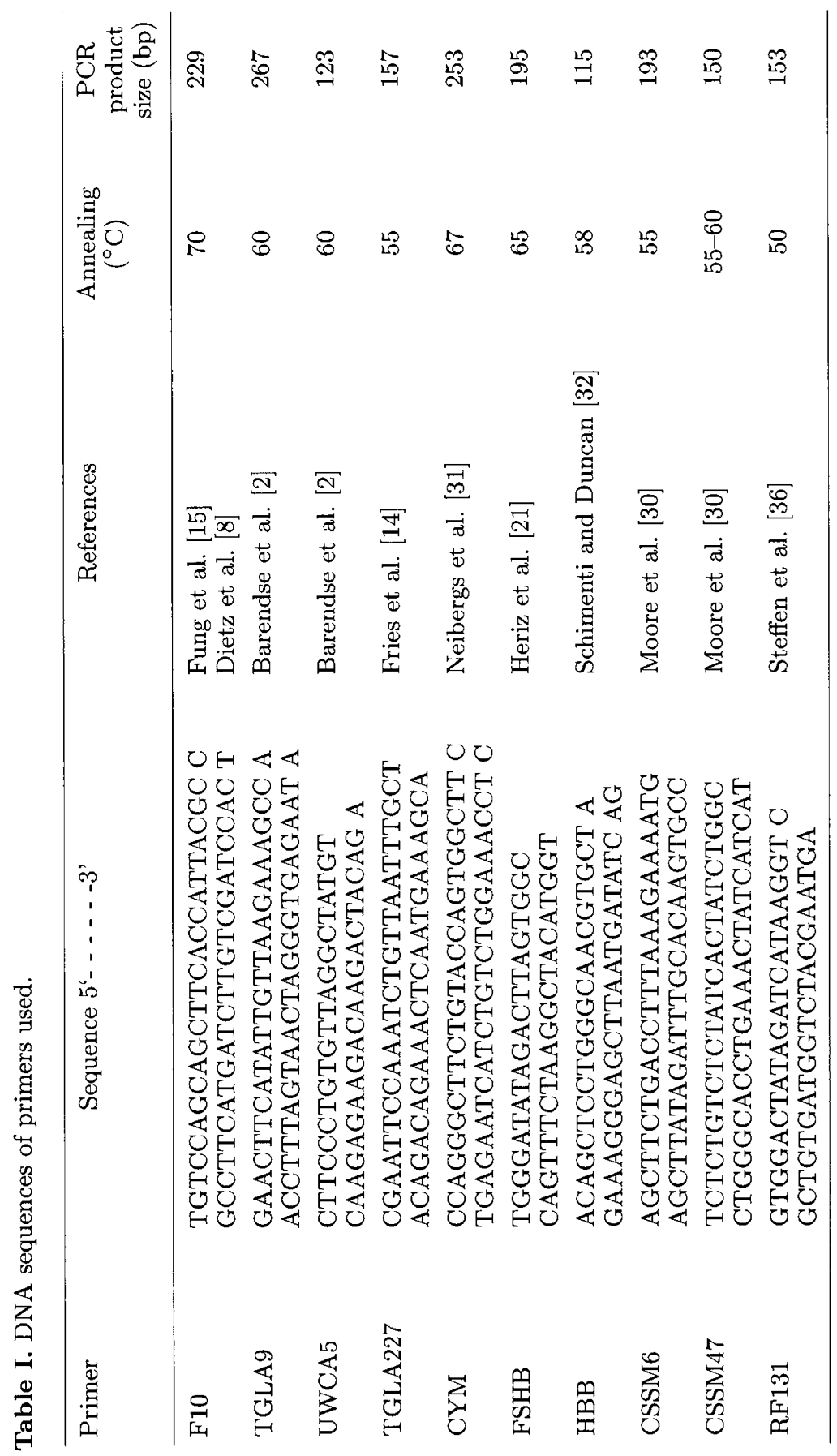




\section{RESULTS AND DISCUSSION}

The present investigation deals with ten PCR primers designed for either coding genes or microsatellites. Microsatellites constitute a powerful tool for mapping the bovine genome $[2,3,12]$, since these DNA markers of unknown function can be exploited as a basis to map genes of economic interest [37]. PCR gene mapping with primers designed from different types of bovine sequences (exons as well as non-coding regions) is very useful when amplifying relatively short fragments (up to $600 \mathrm{bp}$ ), with the annealing portion of the reaction run at the highest possible temperature [8].

The presence or absence of the PCR amplified fragment in each of the 47 hybrid clones determined the assignment of each marker. Results (table II) revealed syntenic relationships between F10-TGLA9, HBB-FSHB and TGLA227-UWCA5, for which the percentage agreement and correlation coefficient, $\varphi$, values exceeded $95.7 \%$ and 0.81 , respectively. The results presented in table II showed that some markers, despite the fact that they had a high percentage agreement $(>90 \%)$ were not syntenic because their estimated $\varphi$ values did not exceed 0.04 . The correlation coefficient, $\varphi$, is considered to be the best discriminating factor for synteny when its value exceeds 0.69 (in 40 independent clones) and it recognizes about twice as many true syntenic pairs as a simple discordant ratio calculation [5].

The six loci investigated, representing three syntenic groups in buffalo, have also been found to be syntenic in cattle. F10 [8] and TGLA9 [2] have been assigned in cattle to syntenic group U27, which has been assigned to cattle chromosome BTA 12 [29]. FSHB and HBB have been mapped to cattle syntenic group U19 [1] and FSHB has been localized on chromosome BTA 15q24-qter [20]. Fries et al. [14] have assigned TGLA227 and UWCA5 to cattle syntenic group U9 and to cattle chromosome BTA 18. TGLA227 and UWCA5 have also been found to be genetically linked [2].

The other markers investigated (CYM, CSSM6, CSSM47 and RF131) have been found to segregate independently from each other and from the three syntenic groups. In cattle, these markers are assigned to different syntenic groups and consequently to different chromosomes. CYM has been assigned to bovine syntenic group U6 and to chromosome BTA 3 [16]. CSSM6 and CSSM47 have been assigned to U12 and U18, respectively [30]. Syntenic group U12 has been mapped to BTA 22 [35] while U18 has been mapped to both BTA 8 [24,33] and BBU3q [33]. RF131 has been mapped to cattle syntenic group U4 [36], which has been located on BTA21 $[13,17]$.

The present study confirms syntenic conservation between cattle and buffalo as previously demonstrated $[6,7,11,32]$. Chromosomal conservation between cattle and buffalo has also been demonstrated, based on the banding homoeology between cattle and river buffalo chromosomes [22]. Genes assigned to specific cattle chromosomes have been assigned to homoeologous buffalo chromosomes $[6,7,10$, $11,18,19,23-28]$. Chromosomal conservation between cattle and buffalo suggests that the localization of the syntenic loci F10-TGLA9, FSHB-HBB and TGLA227UWCA5 could be on buffalo chromosomes BBU 13, BBU 16 and BBU 18, respectively. Comparative mapping also predicts the assignment of CYM, CSSM6, CSSM47 and RF131 to river buffalo chromosomes BBU 6, BBU 21, BBU 3q and 
Table II. Percent concordance and correlation coefficients $(\varphi)$ of the segregation of ten markers tested on 47 buffalo-hamster somatic cell hybrids.

\begin{tabular}{|c|c|c|c|c|c|c|c|c|c|c|}
\hline & CYM & F10 & TGLA9 & CSSM6 & HBB & CSSM47 & FSHB & RF131 & UWCA5 & TGLA227 \\
\hline $\begin{array}{l}\text { CYM } \\
\%\end{array}$ & - & - & - & - & - & - & - & - & - & - \\
\hline$\varphi$ & - & - & - & - & - & - & - & - & - & - \\
\hline $\begin{array}{l}\text { F10 } \\
\%\end{array}$ & 80.8 & - & - & - & - & - & - & - & - & - \\
\hline$\varphi$ & 0.28 & - & - & - & - & - & - & - & - & - \\
\hline $\begin{array}{l}\text { TGLA9 } \\
\%\end{array}$ & 80.8 & 95.7 & - & - & - & - & - & - & - & - \\
\hline$\varphi$ & 0.28 & 0.87 & - & - & - & - & - & - & - & - \\
\hline $\begin{array}{l}\text { CSSM6 } \\
\%\end{array}$ & 82.2 & 88.8 & 88.8 & - & - & - & - & - & - & - \\
\hline$\varphi$ & 0.3 & 0.67 & 0.67 & - & - & - & - & - & - & - \\
\hline $\begin{array}{l}\mathrm{HBB} \\
\%\end{array}$ & 91.4 & 76.6 & 76.6 & 77.7 & - & - & - & - & - & - \\
\hline$\varphi$ & 0.04 & 0.086 & 0.08 & 0.09 & - & - & - & - & - & - \\
\hline $\begin{array}{l}\text { CSSM47 } \\
\%\end{array}$ & 91.5 & 73.9 & 76.0 & 80.0 & 89.1 & - & - & - & - & - \\
\hline$\varphi$ & 0.032 & -0.11 & -0.11 & 0.07 & -0.06 & - & - & - & - & - \\
\hline $\begin{array}{l}\text { FSHB } \\
\%\end{array}$ & 93.6 & 78.7 & 78.7 & 80.0 & 97.9 & 89.4 & - & - & - & - \\
\hline$\varphi$ & -0.03 & 0.15 & 0.15 & 0.16 & 0.80 & -0.05 & - & - & - & - \\
\hline $\begin{array}{l}\text { RF131 } \\
\%\end{array}$ & 70.0 & 72.3 & 72.3 & 73.3 & 70.2 & 71.7 & 72.3 & - & - & - \\
\hline$\varphi$ & 0.22 & 0.26 & 0.26 & 0.29 & 0.03 & 0.10 & 0.11 & - & - & - \\
\hline $\begin{array}{l}\text { UWCA5 } \\
\%\end{array}$ & 80.8 & 82.9 & 82.9 & 86.6 & 80.1 & 78.7 & 82.9 & 76.6 & - & - \\
\hline$\varphi$ & 0.28 & 0.04 & 0.49 & 0.58 & 0.29 & 0.16 & 0.39 & 0.38 & - & - \\
\hline $\begin{array}{l}\text { TGLA227 } \\
\%\end{array}$ & 80.8 & 78.7 & 78.7 & 86.6 & 85.1 & 80.9 & 87.2 & 72.3 & 95.7 & - \\
\hline$\varphi$ & -0.07 & 0.32 & 0.21 & 0.55 & 0.34 & 0.18 & 0.47 & 0.23 & 0.87 & - \\
\hline
\end{tabular}

Two markers are syntenic if $\varphi>0.69$ with an error $Q=0.025$ and a probability of correct decision $P=0.96$. 
BBU 20, respectively. The results presented here need to be confirmed by in-situ hybridization localizations on the river buffalo chromosomes.

\section{ACKNOWLEDGMENTS}

The authors thank Dr J.E. Womack for kindly providing the PCR primers. This research was supported in part by USDA, Office of International Cooperation and Development, National Agriculture Research Project NARP (Egypt), Collaborative research project C008.

\section{REFERENCES}

[1] Barendse W., Armitage S.M., Womack J.E., Hetzel D.J.S., Substantial conservation of gene order of three bovine chromosomal segments when compared to humans, Cytogenet. Cell. Genet. (Abstract) 58 (1991) 2123.

[2] Barendse W., Armitage S.M., Kossarek L.M., Shalom A., Kirkpatrick B.W., Ryan A.M., Clayton D., Li L., Neibergs H.L., Zhang N., Grosse W.M., Weiss J., Creighton P., Mc Carthy F., Ron M., Teale A.J., Fries R., Mc Graw R.A., Moore S.S., Georges M., Soller M., Womack J.E., Hetzel D.J.S., A genetic linkage map of the bovine genome, Nature Genet. 6 (1994) 227-234.

[3] Bishop M.D., Kappes S.M., Keele J.W., Stone R.T., Sunden S.L.F., Howkins D.A., Solinas Toldo S., Fries R., Grosz M.D., Yoo J., Beattie C.W., A genetic linkage map for cattle, Genetics 136 (1994) 619-639.

[4] Blin N., Stafford D.W., A general method for isolation of high molecular weight DNA from eukaryotes, Nucleic Acids Res. 3 (1976) 2303-2308.

[5] Chevalet C., Corpet F., Statistical decision rules concerning synteny or independence between markers, Cytogenet. Cell. Genet. 43 (1986) 132-139.

[6] de Hondt H.A., Bosma A.A., den Bieman M., de Haan N.A., van Zutphen L.F.M., Gene mapping in the river buffalo (Bubalus bubalis L.) Genet. Sel. Evol. 23 (1991) $104 \mathrm{~s}-108 \mathrm{~s}$.

[7] de Hondt H.A., Gallagher D., Oraby H., Othman O.E., Bosma A.A., Womack J.E., El Nahas S.M., Gene mapping in river buffalo (Bubalus bubalis L): five syntenic groups, J. Anim. Breed. Genet. 114 (1996) 79-85.

[8] Dietz A.B., Neibergs H.L., Womack J.E., Assignment of eight loci to bovine syntenic groups: extension of a comparative gene map, Mamm. Genome 3 (1992) 106-111.

[9] Echard G., Gellin J., Gillois M., Localisation des gènes MPI, PKM2, NP sur le chromosome $3 \mathrm{du}$ porc (Sus scrofa L) et analyse cytogénétique d'une lignée de hamster Chinois issue de la DON(Wg3h), Genet. Sel. Evol. 16 (1984) 261-270.

[10] El Nahas S.M., de Hondt H.A., Othman O.E., Bosma A., de Haan N., Assignment of genes to chromosome 4 of the river buffalo with a panel of buffalo-hamster hybrid cells, J. Anim. Breed. Genet. 110 (1993) 182-185.

[11] El Nahas S.M., Oraby H.A., de Hondt H.A., Medhat A.M., Zahran M., Mahfouz E.R., Karim A.M., Synteny mapping in river buffalo, Mamm. Genome 7 (1996) 831-834.

[12] Ferretti L., Urquhart B.G.D., Eggen A., Olsaker I., Harlizius B., Castiglioni B., Mezzelani A., Solinas Toldo S., Thieven U., Zhang Y., Morgan A.L.G., Teres V.M., Schwerin M., Martin-Burriel I., Chowdhary B.P., Erhardt G., Nijman I.J., Cribiu E.P., Barendse W., Leveziel H., Fries R., Williams J.L., Cosmid-derived markers anchoring the bovine genetic map to the physical map, Mamm. Genome 8 (1997) $29-36$. 
[13] Fries R., Threadgill D.W., Hediger R., Gunawardana A., Blessing M., Jarcano J.L., Stranzinger G., Womack J.E., Mapping of bovine cytokeratin sequences to four different sites on three chromosomes, Cytogenet Cell. Genet. 57 (1991) 135-141.

[14] Fries R., Eggen A., Womack J.E. (1993) The bovine genome map, Mamm. Genome 4 (1993) 405-428.

[15] Fung M.R., Campbell R.M., Mac Gillivray R.T.A., Blood coagulation factor X mRNA encodes a single polypeptide chain containing a prepro leader sequence, Nucleic Acid. Res. 12 (1984) 4481-4492.

[16] Gallagher D.S., Grosz M.D., Womack J.E., Skow L.C., Chromosomal localization of HSP70 genes in cattle, Mamm. Genome 4 (1993) 388-390.

[17] Georges M., Gunawardana A., Threadgill D., Lathrop M., Olsaker I., Mishra A., Sargeant L., Schoeberlein A., Steele M., Tery C., Threadgill D.S., Zhao X., Holm T., Fries R., Womack J.E., Characterization of a set of variable number of tandem repeat markers conserved in Bovidae, Genomics 11 (1991) 24-32.

[18] Hassanane M.S., Gu F., Chowdhary B.P., Anderson L., Gustavsson I., In situ hybridization mapping of the immunoglobulin gamma heavy chain (IGHG) gene to chromosome 20q23-q25 in river buffaloes, Hereditas 118 (1993) 285-288.

[19] Hassanane M.S., Chowdhary B.P., Anderson L., Gustavsson I., Mapping the interferon gamma (IFGN) gene in river buffalo and swamp buffaloes by in situ hybridization, Hereditas 120 (1994) 29-33.

[20] Hediger R., Johnson S.E., Hetzel D.J.S., Localization of the beta-subunit of folliclestimulating hormone in cattle and sheep by in situ hybridization, Anim. Genet. 22 (1991) 237-244.

[21] Heriz A., Arruga M.V., Monteagudo L.V., Tejedor M.T., Contribution to cattle gene map by PCR, in: Proc. 11th Europ. Coll. Cytogenet. Domest. Anim., Frederiksberg, 2-5 August 1994, The Royal Vet. \& Agric. Univ., Frederiksberg (Copenhagen), Denmark, 1994, pp. 42-48.

[22] Iannuzzi L., Di Meo G.P., Perucatti A., Ferrara L., A comparison of G- and Rbanding in cattle and river buffalo prometaphase chromosomes, Caryologia 43 (1990) 283-290.

[23] Iannuzzi L., Gallagher D.S., Di Meo G.P., Ryan A.M., Perucatti A., Ferrara L., Irwin D.M., Womack J.E., Chromosomal localization of the lysozyme gene cluster in river buffalo (Bubalus bubalis L), Chromosome Res. 1 (1993) 253-255.

[24] Iannuzzi L., Gallagher D.S., Ryan A.M., Di Meo G.P., Womack J.E., Chromosomal localization of omega and trophoblast interferon genes in cattle and river buffalo by sequential R-banding and fluorescent in situ hybridization, Cytogenet. Cell. Genet. 62 (1993) 224-227.

[25] Iannuzzi L., Gallagher D.S., Womack J.E., Di Meo G.P., Skow L.C., Ferrara L., Chromosomal localization of the major histocompatibility complex in cattle and river buffalo by fluorescent in situ hybridization, Hereditas 118 (1993) 187-190.

[26] Iannuzzi L., Di Meo G.P., Ryan A.M., Gallagher D.S., Ferrara L., Womack J.E., Localization of uridine monophosphate synthase (UMPS) gene to river buffalo chromosome by FISH, Chromosome Res. 2 (1994) 255-256.

[27] Iannuzzi L., Gallagher D.S., Liou L.S., Di Meo G.P., Ryan A.M., Sastry K.N., Womack J.E., Chromosomal localization of conglutinin (CGN1) gene to river buffalo by sequential RBH-banding and FISH, Hereditas 120 (1994) 283-286.

[28] Iannuzzi L., Gallagher D.S., Womack J.E., Di Meo G.P., Shelling C.P., Groenen M.A.M., FISH mapping of the $\alpha$-S2 casein gene on river buffalo and cattle chromosomes identifies a nomenclature discrepancy in the bovine karyotype, Chromosome Res. 4 (1996) 159-162. 
[29] Mezzelani A., Solinas Toldo S., Nocart M., Guerin G., Ferretti L., Fries R., Mapping of syntenic groups U7 and U27 to bovine chromosomes 25 and 12, respectively, Mamm. Genome 5 (1994) 574-576.

[30] Moore S.S., Byrne K., Berger K.T., Barendse W., Mc Carthy F., Womack J.E., Hetzel D.J.S., Characterization of 65 bovine microsatellites, Genome 5 (1994) 84-90.

[31] Neibergs H.L., Dietz A.B., Womack J.E., Single-strand conformation polymorphisms (SSCPs) detected in five bovine genes, Anim. Genet. 24 (1993) 81-84.

[32] Othman O.E., Gallagher D.S. Jr., deHondt H.A., El Nahas S.M., Oraby H.A., Bosma A.A., Womack J., Gene mapping in River Buffalo; Five syntenic groups, Proc. 11th Europ. Coll. Cytogenet. Domest. Anim., Frederiksberg, 2-5 August 1994. The Royal Vet. \& Agric. Univ., Frederiksberg (Copenhagen), Denmark, 1994, pp. 193.

[33] Ryan A.M., Gallagher D.S., Womack J.E., Syntenic mapping and chromosomal localization of bovine $a$ and $\beta$-interferon genes, Mamm. Genome 3 (1992) 575-578.

[34] Schimenti J.C., Duncan C.H., Structure and organization of the bovine $\beta$-globin genes, Mol. Biol. Evol. 2 (1985) 514-525.

[35] Schwerin M., Solinas Toldo S., Eggen A., Brunner R., Seyfert H.M., Fries R., The bovine lactoferrin gene (LTF) maps to chromosome 22 and syntenic group U12, Mamm. Genome 5 (1994) 486-489.

[36] Steffen P., Eggen A., Dietz A.B., Womack J.E., Stranzinger G., Fries R., Isolation and mapping of polymorphic microsatellites in cattle, Anim. Genet. 24 (1993) 121124.

[37] Vaiman D., Mercier D., Eggen A., Bahri-Darwich I., Grohs C., Cribiu E.P., Dolf G., Oustry A., Guérin G., Leveziel H., A genetic and physical map of bovine chromosome 11, Mamm. Genome 5 (1994) 553-556.

[38] Womack J.E., Moll Y.D., Gene map of the cow: conservation of linkage with mouse and man, J. Hered. 77 (1986) 2-7. 